\title{
Desain Alat Ukur Motif Merantau pada Tiga Kelompok Etnik di Indonesia
}

\author{
IHSANA SABRIANI BORUALOGO \\ Fakultas Psikologi Universitas Islam Bandung, Jl. Tamansari No.1 Bandung \\ email : ihsana.sabriani@yahoo.com
}

\begin{abstract}
Indonesia has value of migration which parents teach to their children. There are three big ethnic groups in Indonesia which have different orientation on value of migration. Bataknese mainly migrate for study, Minangnese mainly migrate for work and trading, and Sundanese do not have a certain value of migration, although they do migrate. The aim of this article is to design an instrument for measuring migration motive on Bataknese, Minangnese, and Sundanese. The migration motive scale was tested using SEM to see fitness between conceptual model and empirical model. It was also tested using EFA to explore factor analysis. Results showed the scale has 5 factors and adequate internal consistency. The five factors are: traits needed when migrating, importance of going out of the hometown, importance of having plan when migrating, importance of being able to adjust, and importance of being successful when migrating.
\end{abstract}

Keywords : value of migration, migration motive, cross-cultural psychology, factor analysis, Bataknese, Minangnese, Sundanese.

\begin{abstract}
Abstrak Merantau merupakan suatu nilai budaya yang diajarkan oleh orang tua kepada anak-anaknya. Terdapat tiga kelompok etnik besar di Indonesia yang memiliki kekhasan dalam hal nilai budaya merantau. Kelompok etnik Batak pergi merantau untuk tujuan melanjutkan pendidikan, kelompok etnik Minang pergi merantau untuk tujuan berdagang, sedangkan kelompok etnik Sunda tidak secara khusus memiliki nilai budaya merantau, tetapi masyarakat etnik Sunda juga melakukan aktivitas merantau. Tulisan ini bertujuan untuk mendesain alat ukur motif yang mendasari mahasiswa etnik Batak, Minang, dan Sunda untuk merantau. Pengujian alat ukur motif merantau dilakukan menggunakan SEM untuk menguji kesesuaian antara model konseptual dengan model empirik. Selain itu juga dilakukan pengujian menggunakan EFA untuk mengeksplorasi faktor yang terdapat pada alat ukur tersebut. Hasil menunjukkan bahwa alat ukur motif merantau memiliki 5 faktor dan memiliki internal konsistensi yang tinggi. Kelima faktor tersebut adalah sifat yang dibutuhkan ketika merantau, pentingnya pergi merantau, pentingnya memiliki rencana ketika merantau, pentingnya memiliki kemampuan menyesuaikan diri, dan pentingnya mencapai kesuksesan ketika merantau.
\end{abstract}

Kata kunci : nilai budaya merantau, motif merantau, psikologi lintas budaya, faktor analisis.

\section{Pendahuluan}

Wilayah Indonesia yang luas dan memiliki 13.466 pulau terhubung satu sama lain melalui lautan, memberikan peluang bagi penduduk Indonesia untuk bermigrasi ke pulau yang berbeda. Pada zaman Orde Baru, dikenal konsep transmigrasi untuk mengatasi terjadinya penumpukan penduduk di suatu pulau tertentu. Transmigrasi merupakan perpindahan penduduk dalam jumlah besar dari satu pulau yang padat penduduknya (Pulau Jawa) ke pulau-pulau lain yang tidak terlalu padat penduduknya (Pulau Sumatra dan Pulau Kalimantan). Selain transmigrasi, juga dikenal bentuk migrasi yang lebih bersifat perorangan dengan tujuan tertentu. Bentuk migrasi perorangan ini dikenal sebagai merantau (Borualogo, 2014:1).

Received: 1 Juni 2015, Revision: 14 Oktober 2015, Accepted: 24 Desember 2015

Print ISSN: 0215-8175; Online ISSN: 2303-2499. Copyright@2015. Published by Pusat Penerbitan Universitas (P2U) LPPM Unisba Terakreditasi SK Kemendikbud, No.040/P/2014, berlaku 18-02-2014 s.d 18-02-2019 
Merantau tidak hanya merupakan bentuk perpindahan penduduk, tetapi merupakan suatu nilai budaya yang diajarkan oleh orang tua kepada anak-anaknya yang terdapat pada sejumlah kelompok etnik di Indonesia (Borualogo, $2014: 1$ ).

Di dalam Kamus Bahasa Indonesia, merantau didefinisikan sebagai pergi ke tempat lain untuk mencari penghidupan, ilmu, dll (kbbi.web.id). Merantau untuk tujuan pendidikan, adalah penting dalam upaya untuk meningkatkan kualitas sumber daya manusia. Dengan perkataan lain, adalah penting untuk melakukan revitalisasi dalam bidang pendidikan (Borualogo, 2004:508)

Pergi merantau tidak selalu bermakna berpindah pulau. Merantau berarti pergi meninggalkan tempat asalnya (kampung halaman) dengan kemauan sendiri, untuk jangka waktu tertentu, menuju wilayah/ daerah lain, untuk menjalani kehidupan atau mencari pengalaman (Naim, 2013:3).

Pada umumnya, perantau yang pergi meninggalkan kampung halamannya adalah para perantau berusia remaja yang memiliki harapan-harapan mengenai masa depan di tanah rantau. Walaupun individu dari berbagai kelompok etnik di Indonesia tidak selalu tinggal di daerah asalnya, namun kelompok etnik yang dikenal memiliki nilai budaya merantau adalah etnik Minang dan Batak (Borualogo, 2014:2).

Masyarakat etnik Minang pada umumnya pergi merantau untuk meningkatkan kemampuan finansial. Ini sejalan dengan ciri etnik Minang melalui budaya "manggaleh" (budaya berdagang). Walaupun tidak sedikit etnik Minang yang berhasil di bidang profesi lainnya, namun yang dikenal luas adalah profesi dagang (Latief, 2002:53; Naim, 2013: 172).

Pada umumnya, mereka merantau untuk membuka usaha di bidang jasa yang dibutuhkan orang banyak, seperti rumah makan, tukang jahit, photo copy, toko buku. Selain itu, mereka pun berdakwah melalui kegiatan keagamaan dan yayasan sosial di lingkungan tempat mereka tinggal (Latief, 2002:47). Ketika pergi merantau, mereka diajarkan untuk membaur dengan suku bangsa lain yang diajarkan melalui adat dan budaya "di mano bumi dipijak, di sinan langit dijunjuang" (di mana bumi dipijak, di sana langit dijunjung). Walaupun merantau memiliki nilai positif pada suku Minang, namun H. Ch. N. Latief Dt. Bandaro menjelaskan adanya sejumlah efek negatif dari budaya merantau pada etnik Minang.

Pada umumnya, yang pergi merantau adalah orang-orang muda dari kelompok umur produktif yang memiliki ambisi, keberanian dan kemauan keras untuk berhadapan dengan tantangan hidup rantau yang masih asing. Namun, efek negatifnya adalah, mereka tidak memiliki kemauan untuk kembali ke daerah asalnya guna membangun tanah kelahirannya. Selain itu, menurut H. Ch. N. Latief Dt. Bandaro, terjadi penurunan atau penipisan rasa ke Minangan, penipisan pemahaman atas nilai-nilai dari adat dan budaya Minangkabau serta penipisan solidaritas kekerabatan (2002:48-50).

Pepatah "setinggi-tinggi terbang bangau kembalinya ke kubangan juga" yang dulu menjadi pegangan orang Minang, kini semakin kabur. Hal ini kemudian disiasati dengan kegiatan pulang basamo dan Gebu Minang (Gerakan Seribu Minang). Namun, pulang basamo dianggap belum membudaya seperti halnya tradisi mudik pada suku Jawa. Pulang basamo hanya dilakukan bilo takana (jika teringat) (Latief, 2002:51). Walaupun memiliki banyak kendala, melalui Gebu Minang, perantau mendonasikan pendapatannya untuk membangun daerah asal dan mensinergikan potensi perantau dengan pembangunan daerah. Namun sayangnya, dana yang terkumpul belum dapat dikelola dengan baik, yang menurut $\mathrm{H}$. Ch. N. Latief Dt. Bandaro karena kurangnya respon positif dari masyarakat Minang di Minangkabau karena menurunnya solidaritas kekerabatan (2002:113-119).

Budaya merantau pada etnik Minang berbeda dengan budaya merantau pada etnik Batak. Budaya merantau pada etnik Batak mengajarkan pada individu untuk merantau guna melanjutkan pendidikan pada jenjang yang lebih tinggi (Harahap, 1987:170, 211). Budaya merantau ini diajarkan melalui nilai budaya hamajuon. Nilai budaya ini mengajarkan kepada individu untuk meraih kemajuan di masa depan melalui merantau dan menuntut ilmu serta mengajarkan pentingnya memiliki kegigihan, ketekunan, kemauan keras untuk berusaha dan bekerja, cerdik dan cermat dalam mengatasi situasi dan pandai menyesuaikan diri (Harahap, 1987 : 134, 211).

Budaya merantau ini pada umumnya dilakukan oleh generasi muda usia remaja setelah mereka lulus SMA untuk melanjutkan pendidikan ke luar daerahnya. Pada umumnya, mereka merantau ke Pulau Jawa untuk mengikuti pendidikan di berbagai perguruan 
tinggi di Pulau Jawa (Borualogo, 2014: 4). Bandung merupakan salah satu kota tujuan merantau, karena di Bandung terdapat sejumlah perguruan tinggi berkualitas yang menjadi tujuan perantau untuk melanjutkan pendidikan (Borualogo, 2014: 4).

Jika pada etnik Batak dan Minang terdapat nilai budaya yang secara spesifik mengajarkan masyarakatnya untuk pergi merantau, maka pada etnik Sunda, tidak terdapat nilai budaya yang secara spesifik mengajarkan masyarakatnya untuk merantau. Namun, hal ini tidak berarti bahwa masyarakat etnik Sunda tidak melakukan aktivitas merantau. Masyarakat etnik Sunda meninggalkan daerah asalnya untuk mencari kehidupan yang lebih baik.

Adanya perbedaan nilai budaya merantau pada ketiga kelompok etnik tersebut, menjadikan hal ini sebagai kajian yang menarik di dalam tinjauan Psikologi Lintas Budaya. Peneliti tertarik untuk mengetahui motif yang mendasari mahasiswa dari ketiga kelompok etnik tersebut untuk merantau ke Bandung. Penelitian ini bertujuan untuk mendesain alat ukur motif yang mendasari mahasiswa etnik Batak, Minang, dan Sunda untuk merantau ke Bandung. Proses mendesain alat ukur dilakukan dalam beberapa tahap dengan menggunakan pendekatan Psikologi Lintas Budaya.

Untuk mendesain konstruk alat ukur motif merantau ini, peneliti melakukan tiga tahapan penelitian. Tahap pertama adalah studi pustaka, tahap kedua adalah penelitian pendahuluan pada mahasiswa kelompok etnik Batak yang merantau dan tidak merantau, tahap ketiga adalah mendesain konstruk ukur motif merantau dan mengujinya dengan menggunakan EFA (Exploratory Factor Analysis).

Pada tahap pertama, peneliti melakukan studi pustaka untuk mempelajari nilai budaya merantau pada kelompok etnik Minang dan Batak. Selain itu, karena kota tujuan merantau adalah ke Bandung, maka peneliti juga melakukan kajian pustaka mengenai nilai budaya merantau pada kelompok etnik Sunda (Borualogo, 2011: 4 ).

Untuk mendapatkan pemahaman mengenai nilai budaya merantau pada etnik Minang, peneliti melakukan kajian pustaka pada hasil penelitian yang dilakukan Mochtar Naim mengenai merantau dan pola migrasi suku Minangkabau (Naim, 2013:3). Alasan utama masyarakat etnik Minang untuk merantau adalah karena alasan ekonomi. Beberapa alasan yang mereka sampaikan terkait alasan ekonomi adalah tekanan ekonomi, sulit hidup di kampung, kurang kesempatan kerja di kampung, tidak ada sawah, serta untuk mencari pekerjaan. Alasan kedua bagi masyarakat etnik Minang untuk merantau adalah karena alasan pendidikan dengan menyatakan bahwa mereka ingin melanjutkan studi, menambah ilmu pengetahuan, mencari pengalaman, mencari keterampilan, meluaskan pandangan dan karena kurangnya fasilitas pendidikan di kampung (Naim, 2013: 264).

Pada umumnya, yang pergi merantau adalah orang-orang muda dari kelompok umur produktif yang memiliki ambisi, keberanian, dan kemauan keras untuk berhadapan dengan tantangan hidup rantau yang masih asing. Ketika pergi merantau, mereka juga diajarkan untuk membaur dengan suku bangsa lain yang diajarkan melalui adat dan budaya di mano bumi dipijak, di sinan langit dijunjuang (di mana bumi dipijak, di sana langit dijunjung). Selain itu, mereka pun diajarkan "kalau buyuang pai marantau, induak cari dunsanak cari, induak samang cari dahulu" (kalau buyung pergi merantau, cari orang tua/orang yang dituakan, cari saudara, terlebih dahulu mencari induk semang) $(\mathrm{H}$. Ch. N. Latief Dt. Bandaro, 2002: 48-50).

Studi pustaka juga dilakukan pada kelompok etnik Sunda. Dari ketiga kelompok etnik ini (Batak, Minang dan Sunda), etnik Sunda adalah yang paling rendah memiliki intensitas untuk merantau. Faktor-faktor yang menjadi intensi masyarakat etnik Sunda untuk merantau adalah ekologi, demografi, ekonomi, daya tarik kota dan keresahan politik. Sementara pada etnik Batak dan Minang, selain faktor-faktor tersebut juga terdapat faktor pendidikan dan aspirasi yang lebih tinggi (Naim, 2013:308).

Studi pustaka pada beberapa buku budaya Sunda, tidak secara spesifik menjelaskan mengenai nilai budaya merantau (Suryani, 2010; Rosidi, 2011). Namun, tidak berarti masyarakat etnik Sunda tidak melakukan perantauan. Secara umum dapat dikatakan bahwa, baik pada etnik Batak, Minang dan Sunda, individu pergi merantau meninggalkan tempat asalnya karena memiliki keinginan untuk mendapatkan kehidupan yang lebih baik, mengejar cita-cita, meraih kesuksesan, dan menuntut kemampuan mereka untuk dapat berusaha keras dan gigih dalam upaya mendapatkan kehidupan 
yang lebih baik dan kesuksesan tersebut (Borualogo, 2014: 19).

Pada tahap kedua, peneliti melakukan penelitian pendahuluan pada mahasiswa etnik Batak yang merantau ke Bandung dan mahasiswa etnik Batak yang tidak merantau (tetap tinggal di tanah asalnya) untuk mengetahui pemahaman mereka mengenai nilai budaya hamajuon, makna nilai budaya tersebut bagi diri mereka, serta apakah nilai budaya tersebut masih berlangsung hingga saat ini (Borualogo, 2011: 5).

Hasil penelitian pendahuluan pada 245 orang mahasiswa etnik Batak (yang merantau dan tidak merantau) mengenai nilai budaya hamajuon menjelaskan bahwa 85,72\% responden (210 orang) memahami makna nilai budaya hamajuon yang diterjemahkan sebagai kemajuan, di mana upaya untuk dapat meraih kemajuan tersebut salah satunya dilakukan melalui merantau. Sebanyak 4,48\% responden yang tidak merantau (11 orang) dan $9,8 \%$ responden yang merantau (24 orang) menjelaskan bahwa mereka belum pernah mendengar istilah hamajuon, tetapi mereka memahami bahwa salah satu nilai di dalam budaya Batak adalah pergi merantau untuk mencapai kemajuan. Sebanyak 85,72\% responden (210 orang) menjelaskan bahwa mereka pernah mendengar nilai budaya hamajuon dan bahwa nilai budaya hamajuon ini masih diajarkan oleh orang tua kepada anak-anaknya, terutama ketika mereka mulai duduk di bangku SMA guna mempersiapkan diri melanjutkan pendidikan tinggi ke tanah Jawa.

Para responden memandang nilai budaya hamajuon sebagai nilai yang mengajarkan kemajuan dalam hidup, menentukan hidup ke arah yang lebih baik dan lebih maju daripada orang tua, budaya berpikir maju, kemajuan dalam diri, kemampuan mengatasi masalah dan beradaptasi di situasi sulit, menuntut ilmu setinggi-tingginya, merantau, kegigihan, ambisius, pantang menyerah, tekun, serta mencapai kesuksesan dalam hidup (Borualogo, 2011: 15).

Setelah mendapatkan hasil penelitian pendahuluan mengenai nilai budaya merantau pada mahasiswa etnik Batak, serta mendapatkan pemahaman mengenai merantau pada etnik Minang dan Sunda, maka pada tahap ketiga, peneliti menjaring dalam pertanyaan terbuka mengenai pemaknaan mahasiswa dari ketiga kelompok etnik tentang makna merantau bagi mereka.
Hasil penelitian pendahuluan pada tahap ketiga ini menunjukkan bahwa mahasiswa dari ketiga kelompok etnik memaknakan merantau sebagai nilai-nilai yang mengajarkan kepada individu untuk memiliki budaya berpikir maju, memiliki cita-cita, memiliki kegigihan dan ketekunan dalam meraih cita-cita, memiliki kemauan keras untuk berusaha dan bekerja, cerdik dan cermat dalam mengatasi situasi serta memiliki kemampuan menyesuaikan diri di tanah rantau (Borualogo, 2012: 14).

Berdasarkan hal tersebut, disusunlah alat ukur motif merantau dengan lima domain di dalam alat ukur tersebut, yaitu pentingnya pergi merantau, memiliki kegigihan dan ketekunan, memiliki kemauan keras untuk berusaha dan bekerja, cerdik dan cermat mengatasi situasi serta pandai menyesuaikan diri dalam upaya mencapai cita-cita dalam bidang pendidikan. Alat ukur terdiri dari 44 item, yang akan dijelaskan pada bagian selanjutnya.

\section{Sampel Penelitian}

Sampel penelitian ini berjumlah 712 orang mahasiswa perantau yang berasal dari tiga kelompok etnik (Batak, Minang, dan Sunda), berusia 20-23 tahun dan pergi merantau serta tinggal di Bandung tanpa orang tua. Sampel terdiri dari 234 mahasiswa etnik Batak (165 laki-laki, 69 perempuan), 233 mahasiswa etnik Minang (123 laki-laki, 110 perempuan), dan 245 mahasiswa etnik Sunda (71 laki-laki, 174 perempuan).

Pemilihan sampel dilakukan dengan menggunakan cluster random sampling. Dari hasil random, 25 perguruan tinggi di Bandung terpilih sebagai cluster dalam penelitian ini (Borualogo, 2014:135-136).

\section{Alat Ukur Motif Merantau}

Alat ukur motif merantau didesain oleh peneliti dibawah supervisi Prof. Fons van de Vijver (Profesor Psikologi Lintas Budaya dari Tilburg University, Belanda). Alat ukur terdiri dari 44 item yang disusun dalam bentuk pernyataan menggunakan skala Likert dengan 6 pilihan yang bergerak dari sama sekali tidak penting bagi saya (1) sampai sangat penting bagi saya (6).

Alat ukur nilai budaya merantau ini memiliki 5 domain, yaitu (1) pentingnya pergi merantau, (2) pentingnya memiliki kegigihan dan ketekunan, (3) pentingnya memiliki kemauan keras untuk berusaha dan bekerja, (4) pentingnya untuk cerdik dan cermat 
Tabel 1

Kisi-kisi Alat Ukur Nilai Budaya Merantau

\begin{tabular}{|c|c|c|c|}
\hline Dimensi & Indikator & Contoh Pernyataan & $\begin{array}{l}\text { Nomor } \\
\text { Item }\end{array}$ \\
\hline \multirow[t]{5}{*}{$\begin{array}{l}\text { Pentingnya pergi } \\
\text { merantau }\end{array}$} & $\begin{array}{l}\text { Pentingnya memiliki budaya } \\
\text { berpikir maju }\end{array}$ & $\begin{array}{l}\text { Untuk pergi merantau menuntut ilmu } \\
\text { demi mencapai cita-cita saya }\end{array}$ & $1,17,34,36$ \\
\hline & $\begin{array}{l}\text { Pentingnya memiliki cita-cita } \\
\text { tinggi }\end{array}$ & $\begin{array}{l}\text { Untuk memiliki aspirasi yang harus } \\
\text { saya raih ketika pergi merantau } \\
\text { untuk menuntut ilmu }\end{array}$ & $2,22,38$ \\
\hline & $\begin{array}{l}\text { Pentingnya memiliki } \\
\text { kemauan untuk menerima } \\
\text { pembaharuan }\end{array}$ & $\begin{array}{l}\text { Untuk meningkatkan kualitas } \\
\text { hidup saya melalui merantau untuk } \\
\text { menuntut ilmu }\end{array}$ & 27,40 \\
\hline & $\begin{array}{l}\text { Pentingnya menetapkan } \\
\text { tujuan mengenai prestasi } \\
\text { yang ingin diraih }\end{array}$ & $\begin{array}{l}\text { Untuk menetapkan tujuan ketika } \\
\text { merantau untuk menuntut ilmu }\end{array}$ & 3,30 \\
\hline & $\begin{array}{l}\text { Pentingnya memiliki visi ke } \\
\text { masa depan }\end{array}$ & $\begin{array}{l}\text { Untuk merencanakan kehidupan saya } \\
\text { melalui merantau untuk menuntut } \\
\text { ilmu }\end{array}$ & 4,32 \\
\hline \multirow[t]{4}{*}{$\begin{array}{l}\text { Pentingnya me- } \\
\text { miliki kegigihan } \\
\text { dan ketekunan }\end{array}$} & $\begin{array}{l}\text { Pentingnya belajar dengan } \\
\text { sungguh-sungguh }\end{array}$ & $\begin{array}{l}\text { Untuk memiliki kegigihan dalam } \\
\text { belajar dan menyelesaikan pendi- } \\
\text { dikan saya }\end{array}$ & $5,18,35$ \\
\hline & $\begin{array}{l}\text { Pentingnya menuntaskan } \\
\text { tugas yang dibebankan }\end{array}$ & $\begin{array}{l}\text { Untuk menuntaskan tugas yang } \\
\text { dibebankan pada saya agar } \\
\text { meningkatkan kompetensi saya } \\
\text { dalam bidang yang saya pelajari }\end{array}$ & 6,23 \\
\hline & $\begin{array}{l}\text { Pentingnya merealisasikan } \\
\text { rencana yang telah disusun }\end{array}$ & $\begin{array}{l}\text { Untuk melaksanakan rencana agar } \\
\text { dapat meraih prestasi tinggi }\end{array}$ & 7,28 \\
\hline & $\begin{array}{l}\text { Pentingnya memiliki } \\
\text { semangat/kemauan untuk } \\
\text { tidak mudah menyerah }\end{array}$ & $\begin{array}{l}\text { Untuk tidak mudah menyerah } \\
\text { ketika menghadapi masalah dalam } \\
\text { pendidikan saya }\end{array}$ & $8,31,37$ \\
\hline
\end{tabular}

dalam mengatasi situasi, dan (5) pentingnya memiliki kemampuan untuk menyesuaikan diri.

\section{Analisis Alat Ukur}

Pengujian konstruk alat ukur dilakukan dengan menggunakan SEM (Structural Equation Model) untuk menguji kesesuaian antara model konstruk dengan model empirik. Setelah itu, dilakukan analisis faktor melalui EFA (Exploratory Factor Analysis).

\section{Hasil dan Pembahasan}

Setelah mendapatkan hasil bahwa nilai budaya merantau memiliki makna yang sama di ketiga kelompok etnik, selanjutnya dilakukan pengujian model pengukuran pada alat ukur motif merantau. Terdapat lima domain dalam alat ukur motif merantau, yaitu (1) pentingnya pergi merantau, (2) pentingnya memiliki kegigihan dan ketekunan, (3) pentingnya memiliki kemauan keras untuk berusaha dan bekerja, (4) pentingnya untuk cerdik dan cermat dalam mengatasi situasi, (5) pentingnya memiliki kemampuan menyesuaikan diri.

Pengujian kesesuaian model konstruk pengukuran motif merantau, dilakukan dengan mengajukan hipotesis statistik sebagai berikut:

$H_{0}$ : model pengukuran motif merantau sebagai konstruk yang terintegrasi dari aspek pentingnya pergi merantau, pentingnya memiliki kegigihan dan ketekunan, pentingnya memiliki kemauan keras untuk berusaha dan bekerja, pentingnya untuk cerdik dan cermat dalam mengatasi situasi serta pentingnya memiliki kemampuan untuk menyesuaikan diri, sesuai dengan data empirik.

$H_{1}$ : model pengukuran motif merantau sebagai konstruk yang terintegrasi dari aspek pentingnya pergi merantau, pentingnya memiliki kegigihan dan ketekunan, pentingnya memiliki kemauan keras untuk berusaha dan bekerja, pentingnya untuk cerdik dan cermat dalam mengatasi situasi serta pentingnya memiliki kemampuan 


\section{Lanjutan Tabel 1. Kisi-Kisi Alat Ukur Nilai Budaya Merantau}

\begin{tabular}{|c|c|c|c|}
\hline Dimensi & Indikator & Contoh Pernyataan & Nomor \\
\hline \multirow{3}{*}{$\begin{array}{l}\text { Pentingnya memiliki } \\
\text { kemauan keras } \\
\text { untuk berusaha dan } \\
\text { bekerja }\end{array}$} & $\begin{array}{l}\text { Pentingnya memiliki kemauan } \\
\text { keras akan masa depan yang } \\
\text { sukses }\end{array}$ & $\begin{array}{l}\text { Untuk bekerja keras agar saya } \\
\text { memiliki masa depan yang cerah }\end{array}$ & 9,19 \\
\hline & $\begin{array}{l}\text { Pentingnya untuk } \\
\text { menghadapi tantangan dan } \\
\text { berusaha mengatasinya }\end{array}$ & $\begin{array}{l}\text { Untuk berusaha keras mengatasi } \\
\text { hal-hal baru yang sulit dalam } \\
\text { menjalani pendidikan saya }\end{array}$ & 10,24 \\
\hline & $\begin{array}{l}\text { Pentingnya mencapai prestasi } \\
\text { terbaik agar tujuan tercapai }\end{array}$ & $\begin{array}{l}\text { Untuk memiliki kemauan keras } \\
\text { dalam belajar agar saya mencapai } \\
\text { prestasi tinggi }\end{array}$ & 11,29 \\
\hline \multirow[t]{2}{*}{$\begin{array}{l}\text { Pentingnya untuk } \\
\text { cerdik dan cermat } \\
\text { dalam mengatasi } \\
\text { situasi }\end{array}$} & $\begin{array}{l}\text { Pentingnya memiliki } \\
\text { kemampuan menyelesaikan } \\
\text { masalah sulit }\end{array}$ & $\begin{array}{l}\text { Untuk melakukan apa yang telah } \\
\text { diajarkan orang tua saya mengenai } \\
\text { kemampuan untuk memecahkan } \\
\text { masalah agar saya sukses }\end{array}$ & 12,20 \\
\hline & $\begin{array}{l}\text { Pentingnya mengetahui } \\
\text { apa yang harus dilakukan } \\
\text { untuk mewujudkan ide dan } \\
\text { mencapai tujuan }\end{array}$ & $\begin{array}{l}\text { Untuk memiliki banyak ide agar } \\
\text { dapat mencapai tujuan }\end{array}$ & 13,25 \\
\hline \multirow[t]{3}{*}{$\begin{array}{l}\text { Pentingnya memiliki } \\
\text { kemampuan } \\
\text { menyesuaikan diri }\end{array}$} & $\begin{array}{l}\text { Pentingnya memiliki } \\
\text { kemampuan menyesuaikan } \\
\text { diri dengan kehidupan } \\
\text { kampus }\end{array}$ & $\begin{array}{l}\text { Untuk menyesuaikan diri dengan } \\
\text { teman baru di kampus }\end{array}$ & 14,21 \\
\hline & $\begin{array}{l}\text { Pentingnya memiliki } \\
\text { kemampuan untuk } \\
\text { menyesuaikan diri hidup } \\
\text { berjauhan dari orang tua }\end{array}$ & $\begin{array}{l}\text { Untuk menyesuaikan diri hidup } \\
\text { berjauhan dari orang tua }\end{array}$ & 15,26 \\
\hline & $\begin{array}{l}\text { Pentingnya memiliki } \\
\text { kemampuan untuk tinggal } \\
\text { di tempat yang berbeda dari } \\
\text { tempat asal }\end{array}$ & $\begin{array}{l}\text { Untuk menyesuaikan diri dengan } \\
\text { kehidupan yang berbeda di tempat } \\
\text { saya melanjutkan pendidikan }\end{array}$ & 16,33 \\
\hline
\end{tabular}

untuk menyesuaikan diri, tidak sesuai dengan data empirik.

Berikut ini adalah hasil pengukuran model konstruk dari motif merantau.

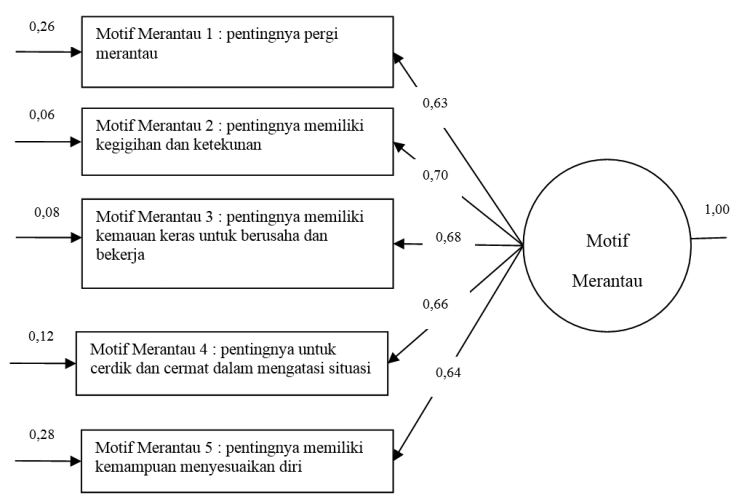

Chi-Square $=44.98, d f=5$, $p$-value $=0.10000$, RMSEA $=0.016$

Gambar 1

Hasil Model Pengukuran Motif Merantau
Gambar 1 menunjukkan bahwa model pengukuran motif merantau, sesuai dengan data empirik (Chi-Square $=44.98$, untuk $\mathrm{df}=5$ dengan p-value $=0.10000$, RMSEA $=0.016$, GFI $=0.98, \mathrm{RMR}=0.011$, AGFI = 0.93). Artinya, model pengukuran motif merantau ini valid untuk digunakan pada sampel penelitian ini.

Berdasarkan model pengukuran di atas, dapat disimpulkan bahwa konstruk motif merantau pada mahasiswa etnik Batak, Minang, dan Sunda yang merantau ke Bandung terukur melalui pentingnya pergi merantau, pentingnya memiliki kegigihan dan ketekunan, pentingnya memiliki kemauan keras untuk berusaha dan bekerja, pentingnya untuk cerdik dan cermat dalam mengatasi situasi serta pentingnya memiliki kemampuan untuk menyesuaikan diri. Aspek-aspek ini adalah nilai-nilai yang diajarkan orang tua kepada para mahasiswa ketika akan merantau sehingga mereka memiliki kemauan dan kemampuan untuk dapat mengatasi masalahmasalah dan kesulitan-kesulitan di tanah 
rantau.

Peneliti juga melakukan exploratory factor analysis (EFA) untuk mengidentifikasi muatan faktor pada ketiga kelompok etnik tersebut. Berdasarkan Eigenvalues lebih besar dari 1, terdapat 5 komponen yang diekstraksi dan dapat diinterpretasikan. Kelima faktor tersebut menjelaskan $50.2 \%$ varians. Tabel 2 menunjukkan kelima faktor dari alat ukur nilai budaya merantau.

Berdasarkan klasifikasi tersebut, maka konstruk motif merantau pada ketiga kelompok etnik didefinisikan sebagai ciri-ciri (1) sifat yang dibutuhkan ketika merantau, (2) pentingnya pergi merantau, (3) pentingnya memiliki rencana ketika merantau, (4) pentingnya memiliki kemampuan menyesuaikan diri, dan (5) pentingnya mencapai kesuksesan ketika merantau. Muatan faktor dari alat ukur ini, disajikan pada tabel 2.

Konsistensi internal dari kelima faktor tersebut adalah .96,.91, .78. .70, and .93. Artinya, alat ukur motif merantau tersebut menunjukkan keadekuatan konsistensi internal.

Tabel 2

Nomor Item Alat Ukur Motif Merantau dan Muatan Faktornya

\begin{tabular}{|c|c|c|c|c|c|}
\hline No & Faktor & Faktor & Faktor & Faktor & Faktor \\
\hline 1. & .39 & .75 & .12 & .12 & .03 \\
\hline 2. & .28 & .79 & .07 & .05 & .03 \\
\hline 3. & .45 & .71 & .11 & .15 & .05 \\
\hline 4. & .38 & .76 & .04 & .04 & .06 \\
\hline 5. & .26 & .09 & .06 & .04 & .93 \\
\hline 6. & .69 & .25 & .14 & .22 & .10 \\
\hline 7. & .73 & .21 & .22 & .19 & .09 \\
\hline 8. & .76 & .28 & .19 & .12 & .09 \\
\hline 9. & .76 & .29 & .13 & .17 & .10 \\
\hline 10. & .72 & .25 & .16 & .16 & .09 \\
\hline 11. & .69 & .25 & .26 & .37 & .07 \\
\hline 12. & .58 & .26 & .19 & .47 & .04 \\
\hline 13. & .59 & .28 & .16 & .46 & .06 \\
\hline 14. & .35 & .14 & .24 & .71 & .09 \\
\hline 15. & .06 & .13 & .09 & .18 & .94 \\
\hline 16. & .09 & .16 & -.00 & .47 & .04 \\
\hline 17. & .14 & .41 & .00 & .19 & .00 \\
\hline 18. & .62 & .34 & .20 & .44 & .07 \\
\hline 19. & .65 & .29 & .21 & .37 & .06 \\
\hline 20. & .55 & .24 & .24 & .49 & .06 \\
\hline 21. & .34 & .15 & .23 & .75 & .07 \\
\hline 22. & .56 & .22 & .20 & .56 & .03 \\
\hline 23. & .60 & .20 & .28 & .43 & .07 \\
\hline 24. & .62 & .24 & .28 & .44 & .07 \\
\hline 25. & .50 & .20 & .22 & .51 & .09 \\
\hline
\end{tabular}

\begin{tabular}{|l|l|l|l|l|l|}
\hline 26. & .23 & .59 & .15 & .34 & .15 \\
\hline 27. & .17 & .73 & .21 & .28 & .08 \\
\hline 28. & .50 & .29 & .51 & .24 & .08 \\
\hline 29. & .21 & .09 & .40 & .03 & .05 \\
\hline 30. & .61 & .26 & .52 & .19 & .05 \\
\hline 31. & .61 & .22 & .47 & .26 & .03 \\
\hline 32. & .25 & .67 & .39 & .12 & .04 \\
\hline 33. & .25 & .40 & .378 & .41 & .06 \\
\hline 34. & .18 & .67 & .45 & .15 & .05 \\
\hline 35. & .57 & .26 & .56 & .16 & .04 \\
\hline 36. & -.16 & .45 & .42 & .08 & .12 \\
\hline 37. & .57 & .19 & .54 & .23 & .06 \\
\hline 38. & .16 & .61 & .51 & .18 & .04 \\
\hline 39. & .56 & .25 & .54 & .21 & .05 \\
\hline 40. & .20 & .56 & .47 & .27 & .03 \\
\hline 41. & .55 & .262 & .55 & .25 & .02 \\
\hline 42. & .26 & .08 & .52 & .50 & .04 \\
\hline 43. & .42 & .17 & .53 & .42 & .01 \\
\hline 44. & .56 & .18 & .58 & .21 & .04 \\
\hline
\end{tabular}

Tabel 2 memerlihatkan kecondongan muatan faktor. Setelah mendapatkan keseluruhan muatan faktor dari seluruh items, maka selanjutnya dilakukan klasifikasi untuk mendapatkan kecondongan muatan faktor pada tiap item. Pada Tabel 2 di atas, telah dicetak tebal pada tiap item yang memiliki kecondongan muatan faktor, apakah pada faktor 1, faktor, 2, faktor 3, faktor 4, ataukah pada faktor 5 . Setelah itu, barulah dilakukan klasifikasi untuk dapat mendefinisikan faktorfaktor tersebut. Berikut ini adalah hasil klasifikasi dari kelima faktor tersebut.

Faktor 1: Sifat yang dibutuhkan ketika merantau (item nomor $6,7,8,9,10,11,12$, $13,18,19,20,22,23,24,28,30,31,35$, $37,39)$

Faktor 2: Pentingnya pergi merantau (item nomor 1, 2, 3, 4, 17, 26, 27, 32, 34, $36,38,40)$.

Faktor 3: Pentingnya memiliki rencana ketika merantau (item nomor 28, 29, 41, 42, 43, 44).

Faktor 4: Pentingnya memiliki kemampuan menyesuaikan diri (item nomor $14,16,21,25,33)$.

Faktor 5: Pentingnya mencapai kesuksesan ketika merantau (item nomor 5, 15)

Setelah melakukan klasifikasi faktor dan mendefinisikannya, maka berikutnya dilakukan pengujian nilai rerata alat ukur motif merantau pada tiap kelompok etnik. Hasil pengujian disajikan pada Tabel 3 . 
menunjukkan bahwa secara umum, kelompok etnik Batak memiliki nilai rerata tertinggi dibandingkan ketiga kelompok etnik lainnya. Artinya, hal ini menjelaskan bahwa motif merantau dipandang lebih penting oleh kelompok etnik Batak daripada kelompok etnik Minang dan Sunda.

Bagi kelompok etnik Batak, pergi merantau tidak sekadar pergi meninggalkan tanah kelahirannya, tetapi juga memiliki makna melaksanakan nilai budaya yang diajarkan secara turun temurun oleh orang tua kepada anak-anaknya. Mereka menyadari bahwa ketika pergi merantau, mereka menyadari pentingnya pergi merantau dan memiliki rencana yang matang sebelum pergi merantau. Mereka juga menyadari bahwa mereka harus memiliki sifat-sifat positif yang dibutuhkan agar mereka dapat meraik kesuksesan di tanah rantau, agar dapat menyesuaikan diri di tanah rantau dengan baik, dan mencapai kesuksesan yang diharapkan oleh diri pribadi maupun orang tua.

Pada etnik Minang, walaupun nilai budaya merantau diajarkan oleh orang tua kepada anak-anaknya, namun motif yang mendasari kegiatan meninggalkan tanah kelahirannya tidaklah sekuat motif yang mendasari kelompok etnik Batak. Hal ini terjadi, karena pada etnik Minang, juga terdapat nilai yang mengharapkan mereka kembali ke kampung halaman setelah sukses guna membangun kemajuan di kampung halamannya.

Sedangkan pada kelompok etnik Sunda, motif merantau tidak terlalu tinggi. Hal ini terjadi karena secara spesifik memang tidak ditemukan adanya nilai yang secara khusus mengajarkan pergi merantau, walaupun masyarakat kelompok etnik Sunda juga melakukan perantauan.

Tabel 3

Nilai Rerata Alat Ukur Motif Merantau pada Tiap Kelompok Etnik

\begin{tabular}{|c|c|c|c|c|c|c|}
\hline 旡 & 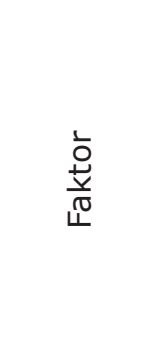 & 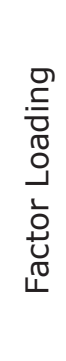 & $\begin{array}{l}\frac{\pi}{\pi} \\
\frac{\pi}{\alpha} \\
\frac{\alpha}{2} \\
\frac{\pi}{Z}\end{array}$ &  & 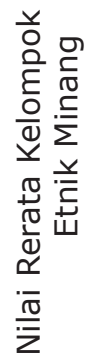 & 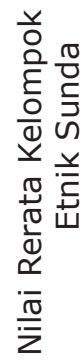 \\
\hline 1 & Faktor 1. & .75 & 4.86 & 5.24 & 4.93 & 4.44 \\
\hline
\end{tabular}

\begin{tabular}{|c|c|c|c|c|c|c|}
\hline 2 & Faktor 1. & .79 & 4.59 & 4.96 & 4.58 & 4.26 \\
\hline 3 & Faktor 1. & .71 & 4.86 & 5.22 & 4.86 & 4.52 \\
\hline 4 & Faktor 1. & .76 & 4.94 & 5.27 & 4.94 & 4.64 \\
\hline 5 & Faktor 2. & .93 & 5.31 & 5.36 & 5.16 & 5.42 \\
\hline 6 & Faktor 2. & .69 & 5.12 & 5.27 & 4.99 & 5.09 \\
\hline 7 & Faktor 2. & .73 & 5.08 & 5.21 & 4.91 & 5.12 \\
\hline 8 & Faktor 2. & .76 & 5.18 & 5.31 & 5.13 & 5.11 \\
\hline 9 & Faktor 3. & .76 & 5.33 & 5.43 & 5.29 & 5.29 \\
\hline 10 & Faktor 3. & .72 & 5.25 & 5.35 & 5.20 & 5.20 \\
\hline 11 & Faktor 3. & .69 & 5.04 & 5.10 & 4.95 & 5.08 \\
\hline 12 & Faktor 4. & .58 & 5.09 & 5.16 & 5.01 & 5.09 \\
\hline 13 & Faktor 4. & .59 & 5.11 & 5.20 & 5.03 & 5.10 \\
\hline 14 & Faktor 5. & .71 & 4.97 & 5.01 & 4.90 & 5.00 \\
\hline 15 & Faktor 5. & .94 & 5.05 & 5.11 & 4.95 & 5.09 \\
\hline 16 & Faktor 5. & .47 & 5.07 & 5.07 & 5.02 & 5.13 \\
\hline 17 & Faktor 1. & .41 & 5.02 & 5.18 & 4.96 & 4.91 \\
\hline 18 & Faktor 2. & .62 & 5.22 & 5.28 & 5.19 & 5.17 \\
\hline 19 & Faktor 3. & .65 & 5.30 & 5.38 & 5.27 & 5.27 \\
\hline 20 & Faktor 4. & .55 & 5.15 & 5.21 & 5.11 & 5.14 \\
\hline 21 & Faktor 5. & .75 & 5.00 & 5.08 & 4.88 & 5.04 \\
\hline 22 & Faktor 1. & .56 & 5.15 & 5.18 & 5.07 & 5.19 \\
\hline 23 & Faktor 2. & .60 & 5.10 & 5.15 & 4.98 & 5.15 \\
\hline 24 & Faktor 3. & .62 & 5.10 & 5.16 & 5.06 & 5.07 \\
\hline 25 & Faktor & .51 & 5.06 & 5.16 & 4.89 & 5.15 \\
\hline 26 & Faktor 5. & .59 & 4.94 & 5.10 & 5.06 & 4.67 \\
\hline 27 & Faktor 1. & .73 & 4.95 & 5.19 & 5.01 & 4.66 \\
\hline 28 & Faktor 2. & .51 & 4.90 & 5.02 & 4.76 & 4.92 \\
\hline 29 & Faktor 3. & .40 & 5.11 & 5.36 & 4.90 & 5.08 \\
\hline 30 & Faktor 1. & .61 & 5.13 & 5.22 & 5.04 & 5.14 \\
\hline 31 & Faktor 2. & .61 & 5.19 & 5.30 & 5.12 & 5.14 \\
\hline 32 & Faktor 1. & .67 & 4.86 & 5.11 & 4.86 & 4.63 \\
\hline 33 & Faktor 5. & .41 & 4.96 & 5.07 & 4.96 & 4.85 \\
\hline 34 & Faktor 1. & .67 & 4.77 & 5.12 & 4.68 & 4.52 \\
\hline 35 & Faktor 2. & .57 & 5.16 & 5.30 & 5.04 & 5.13 \\
\hline 36 & Faktor 1. & .45 & 3.95 & 4.27 & 3.88 & 3.72 \\
\hline 37 & Faktor 2. & .57 & 5.08 & 5.17 & 4.99 & 5.08 \\
\hline 38 & Faktor 1. & .61 & 4.78 & 5.02 & 4.74 & 4.6 \\
\hline 39 & Faktor 3. & .56 & 5.03 & 5.17 & 4.94 & 5.00 \\
\hline 40 & Faktor 1. & .56 & 4.87 & 5.04 & 4.84 & 4.73 \\
\hline 41 & Faktor 3. & .55 & 5.16 & 5.25 & 5.07 & 5.14 \\
\hline 42 & Faktor 5. & .52 & 4.99 & 5.03 & 4.89 & 5.05 \\
\hline 43 & Faktor 4. & .53 & 5.07 & 5.17 & 4.93 & 5.11 \\
\hline 44 & Faktor 3. & .58 & 5.18 & 5.24 & 5.10 & 5.21 \\
\hline & & & & & \\
\hline
\end{tabular}

Faktor 1: Sifat yang dibutuhkan ketika merantau. Faktor 2: Pentingnya pergi merantau. Faktor 3:Pentingnya memiliki rencana ketika merantau. Faktor 4: Pentingnya memiliki kemampuan menyesuaikan diri. Faktor 5: Pentingnya mencapai kesuksesan ketika merantau.

Hasil penelitian yang dilakukan oleh Septiawan Santana dan Suriani (2009) pada mahasiswa Indonesia di Australia dan Kanada, menunjukkan bahwa terdapat 
kekhasan budaya akademik yang dialami oleh mahasiswa Indonesia yang kuliah di luar negeri. Hal ini menunjukkan bahwa kegiatan merantau untuk melanjutkan pendidikan, tidak hanya dilakukan di dalam wilayah Indonesia saja, tetapi juga merantau ke luar wilayah Indonesia.

Dengan kondisi demikian, adalah menarik untuk bisa dilakukan kajian motif merantau pada mahasiswa Indonesia yang merantau ke luar negeri dengan menggunakan pendekatan Psikologi Lintas Budaya, sehingga diperoleh gambaran yang komprehensif mengenai budaya dan motif merantau.

\section{Simpulan dan Saran}

Alat ukur motif merantau memiliki lima faktor yang terdiri dari: (1) sifat yang dibutuhkan ketika merantau, (2) pentingnya pergi merantau, (3) pentingnya memiliki rencana ketika merantau, (4) pentingnya memiliki kemampuan menyesuaikan diri, dan (5) pentingnya mencapai kesuksesan ketika merantau. Alat ukur motif merantau ini memiliki internal konsistensi yang tinggi, sehingga dapat digunakan untuk mengukur motif merantau pada mahasiswa.

Untuk penelitian lanjutan, alat ukur motif merantau ini dapat diujicobakan pada mahasiswa perantau yang datang dari kelompok etnik lainnya (selain kelompok etnik Batak, Minang, dan Sunda) yang pergi merantau meninggalkan daerah asalnya menuju perkotaan di Indonesia. Selain itu, banyaknya jumlah mahasiswa Indonesia yang melanjutkan pendidikan ke luar wilayah Indonesia, maka alat ukur ini juga dapat diujicobakan pada mahasiswa perantau asal Indonesia yang pergi merantau ke luar wilayah Indonesia. Dengan demikian, dapat diperoleh data yang bersifat komprehensif mengenai motif merantau pada mahasiswa Indonesia yang merantau di dalam negeri dibandingkan dengan yang merantau ke luar negeri.

\section{Ucapan Terima Kasih}

Terimakasih kepada Prof. Fons van de Vijver (Tilburg University, Belanda) yang telah membimbing penulis dalam mendesain alat ukur nilai budaya merantau dengan menggunakan pendekatan Psikologi Lintas Budaya.

\section{Daftar Pustaka}

Borualogo, I.S. (2004). "Rekonstruksi Dan Revitalisasi Pendidikan Indonesia Guna Meningkatkan Kualitas Bangsa." Mimbar - Jurnal Sosial dan Pembangunan Vol. 20, No. 4.

Borualogo, I. S. (2011). "Persepsi Remaja Batak Toba dan Mandailing di Medan Mengenai 9 Nilai Budaya Batak." Penelitian Mandiri.

Borualogo, I. S. (2012). "Persepsi Remaja Batak di Bandung Terhadap Nilai Budaya Hamajuon dan Sistem Kekerabatan Dalihan $\mathrm{Na}$ Tolu Dalam Pembentukan Resilience." Penelitian Mandiri.

Borualogo, I. S. (2012b). "Hubungan Antara Resilience Building Block dengan Resilience dan Keterkaitannya dengan Self Esteem Pada Mahasiswa Fakultas Psikologi UNISBA." Prosiding Seminar Nasional Penelitian dan PKM: Sosial, Ekonomi dan Humaniora, 33-40. Bandung, Indonesia: Pusat Penerbitan Universitas (P2U-LPPM) Unisba.

Borualogo, I. S. (2014). "Pengaruh Nilai Budaya Merantau, Sistem Nilai, dan Dukungan Sosial Yang Dimediasi Harga Diri Terhadap Kepegasan Sebagai Penentu Kepuasan Akan Hidup - Suatu Studi Psikologi Lintas Budaya Pada Mahasiswa Perantau Etnik Batak, Minang, dan Sunda di Bandung." Disertasi: Program Pascasarjana Universitas Padjadjaran.

Cohen, A. (2004). Urban Ethnicity. Edited by Abner Cohen. London: Routledge.

Harahap, B. H. (1987). "Orientasi Nilai-Nilai Budaya Batak-Suatu Pendekatan Terhadap Perilaku Batak Toba dan AngkolaMandailing." Jakarta, Indonesia: Sanggar Willem Iskander.

Latief, H. Ch. N. Dt. Bandaro. (2002). Etnis dan Adat Minangkabau. Bandung, Indonesia: Penerbit Angkasa.

Rosidi, Ajip. (2011). Kearifan Lokal Dalam Perspektif Budaya Sunda. Bandung, Indonesia: Kiblat.

Santana K, Septiawan dan Suriani. (2009). "Budaya Akademik Internasional Mahasiswa Indonesia di Australia dan Kanada." Mimbar - Jurnal Sosial dan Pembangunan, Vol. 25, No. 2.

Suryani NS, Elis. (2010). Ragam Pesona Budaya Sunda. Bogor, Indonesia: Ghalia Indonesia

Van de Vijver, F. J. R., \& Hambleton, R. K. (1996). Translating tests: Some practical guidelines. Journal of European Psychologist, 1, 89-99.

Van de Vijver, F. J. R., Hofer, J., \& Chasiotis A. (2010). "Methodological aspects of crosscultural developmental studies. In M. H. Bornstein (Ed.)," Handbook of cultural developmental science (pp. 21-37). Florence, KY: Taylor \& Francis.

Van de Vijver, F. J. R., \& Leung, K. (1997). Methods and data analysis for crosscultural research.Thousand Oaks, CA: 
IHSANA SABRIANI B. Desain Alat Ukur Motif Merantau pada Tiga Kelompok Etnik di Indonesia

Sage.

Van de Vijver, F. J. R., \& Leung, K. (2000). Methodological issues in psychological research on culture. Journal of CrossCultural Psychology, 31, 33-51. DOI: $10.1177 / 0022022100031001004$

Vergouwen, J.C. (1986). Masyarakat dan Hukum
Adat Batak Toba / Kata Pengantar Prof. Dr. T.O Ihromi. Jakarta : Pustaka Azet.

Warnaen, S.. (1979). Stereotip Etnik di Dalam Suatu Bangsa Multietnik - Suatu Studi Psikologi Sosial di Indonesia. Disertasi, Jakarta: Universitas Indonesia. 